$\stackrel{\circ}{i}$

|l|

\title{
KOMUNIKACJA INTERPERSONALNA W INTERAKCJACH SPOŁECZNYCH
}

ABSTRACT. Stefan Frydrychowicz, Komunikacja interpersonalna w interakcjach społecznych [Interpersonal communication in social interactions] edited by M. Obrębska, L. Bakiera, "Człowiek i Społeczeństwo" vol. L: Psychologiczne konteksty komunikacji interpersonalnej [Psychological contexts of interpersonal communication], Poznań 2020, pp. 13-29, Adam Mickiewicz University. ISSN 02393271, https://doi.org/10.14746/cis.2020.50.2.

This article concentrates on the characterization of the transition from social interactions to interpersonal communication. For this purpose analysis of the structure of communication process was conducted on two levels: general and specific. The former focuses on the conditions of the transition from interaction to communication, and further to contact. The latter offers the analysis of the dimensions of interpersonal communication. The conclusion deals with the importance of interlocutors' intentionality as well as appropriate regulation and coordination of the dimensions of communication for effective communication.

Keywords: interaction, communication, contact

Stefan Frydrychowicz, Akademia Ignatianum w Krakowie, Instytut Psychologii, Katedra Psychologii Społecznej i Komunikacji Interpersonalnej, ul. M. Kopernika 26, 31-501 Kraków, stefan.frydrychowicz@ ignatianum.edu.pl, ORCID: https://orcid.org/0000-0001-8318-6880.

\section{Wprowadzenie}

W niniejszym artykule zostanie zarysowany problem przejścia od interakcji społecznych do komunikacji interpersonalnej. Nastąpi omówienie uwarunkowań tego przejścia, związanych ze strukturą procesu komunikacji i jego realizacją przez nadawcę i odbiorcę (dalej oznaczanych N i O), a także scharakteryzowana zostanie struktura procesu komunikacji interpersonalnej. 
Analizując proces komunikacji interpersonalnej, można wskazać na jego podstawowe cechy. Jest on współtworzony przez $\mathrm{N}$ i O, chociaż nie zawsze ich wkład bywa proporcjonalny. Proces ten zachodzi w pewnej sytuacji i w związku z tym w określonym czasie i przestrzeni. Komunikacja interpersonalna jest uwarunkowana zarówno indywidualnie, jak i społecznie. Szersze tło dla procesu komunikacji interpersonalnej stanowi przestrzeń międzyludzka - tworzona przez relacje jednostki z innymi oraz przez relacje wiążące członków takich zbiorowości jak grupy, wspólnoty, organizacje itd. (Sztompka, 2016).

Komunikowanie się jest jednym z wielu złożonych procesów wchodzących w skład całościowego systemu czynności i działań człowieka. Proces stanowi serię kroków lub etapów progresywnie rozwijających się w kierunku określonego celu, stanu końcowego (Frydrychowicz, 1999), a w przypadku procesu komunikacji celem tym jest efektywne komunikowanie się, prowadzące czasami do nawiązania kontaktu między N i O. Proces bywa również łączony ze zmianą w organizacji elementów i struktur, np. języka (Crystal, 1990). Możliwe jest więc strukturalne i czynnościowe (dynamiczne) ujęcie procesu. Ludwig von Bertalanffy (1984), rozpatrując zależności między procesem a strukturą, zauważa, że struktury są wyrazem przepływu procesów, natomiast sama struktura to porządek części.

Poddamy zatem analizie proces komunikacji - ujmując go strukturalnie i czynnościowo. Poniżej omówimy dwa rodzaje ustrukturowania tego procesu - jedno ogólne, związane z przechodzeniem od interakcji do komunikacji i dalej do kontaktu. Czynnościowe ujęcie procesu komunikacji będzie tutaj polegało na scharakteryzowaniu warunków i zarysowaniu mechanizmu tego przejścia. Drugie - bardziej szczegółowe, będzie dotyczyć wybranych form zmienności powyższego procesu i mechanizmu ich scalania.

W pierwszej części artykułu scharakteryzujemy pojęcia interakcji, komunikacji, kontaktu oraz spróbujemy odpowiedzieć na dwa pytania: 1. jaka jest ich natura? oraz 2. kiedy jest możliwe przejście od interakcji do komunikacji i dalej do kontaktu?

Zaznaczyliśmy powyżej, że szczegółowy poziom analizy procesu komunikacji interpersonalnej dotyczy jego form zmienności. Formy zmienności są podstawowymi elementami konstytuującymi ten proces i zmieniającymi się w trakcie jego trwania. Przykładem mogą być tutaj wymiary komunikacji czy też parametry werbalne/niewerbalne tego procesu. W drugiej części artykułu zostaną zatem omówione cztery wymiary komunikacji interpersonalnej: informacyjny, emocjonalno-energetyczny, współdziałania (wspólnego wykonywania czegoś) i relacyjny. Inne formy zmienności procesu komunikacji 
zostaną świadomie pominięte ze względu na ograniczone ramy artykułu. Stawiamy tutaj następujące pytania: 1. jaka jest natura wymiarów komunikacji interpersonalnej i pełniona przez nie funkcja? oraz 2. jak dochodzi do ich integracji w procesie komunikacji interpersonalnej?

W trzeciej części artykułu omówione zostaną uwarunkowania efektywnej komunikacji związane z przechodzeniem interlokutorów od interakcji do komunikacji i niekiedy do kontaktu oraz z integrowaniem wymiarów komunikacji.

\section{Interakcja - komunikacja - kontakt}

W niniejszej pracy przyjmujemy założenie, że w procesie komunikacji interpersonalnej następuje przejście od interakcji do komunikacji i do kontaktu. Oznacza to, że uczestnicy procesu komunikacji wpierw wchodzą ze sobą w interakcję, następnie - będąc w interakcji - komunikują się i czasami nawiązują między sobą kontakt. Tym samym interakcja, komunikacja i kontakt mogą być uznane za etapy procesu komunikacji.

Osoby wchodzą w interakcje, ponieważ pozwala im to zaspokajać potrzeby oraz osiągać różnorodne cele. Czynności te wymagają współdziałania oraz wywierania wpływu. Ponadto instytucje społeczne, takie jak szkoły, szpitale i inne organizacje, powołane zostały do zaspokajania potrzeb społecznych, a to implikuje zachodzenie w nich interakcji społecznych. Czym są zatem: interakcja społeczna, interakcja, komunikacja i kontakt?

Arthur S. Reber i Emily S. Reber (2008: 290) w Słowniku psychologii interakcję i interakcję społeczną definiują w następujący sposób: „Interakcja (interaction) [to] wzajemne oddziaływanie lub wpływ. Mówiąc o interakcji społecznej, mamy na myśli fakt, że czyjeś zachowanie działa jak bodziec na czyjeś inne zachowanie i na odwrót”. Warto zauważyć, że podana definicja interakcji społecznej jest zbieżna z pojęciem sytuacji społecznej, w której według Włodzimierza Szewczuka (1974: 24): ,zachowanie jednostki zdeterminowane jest reakcjami innych ludzi lub ulega modyfikacjom ze względu na obecność innej osoby lub osób”. Z kolei Maria Tyszkowa (1990) uważa, że interakcja jest takim rodzajem kontaktu, w którym osoby stanowią dla siebie nawzajem (dzięki percepcji osób i ich zachowania się) bodźce wpływające na zmianę w zachowaniu. Oznacza to, że $\mathrm{N}$ i O wzajemnie siebie wyodrębniają z otoczenia i wzajemnie reagują na swoje zachowania.

W przytoczonych powyżej definicjach interakcji społecznej, sytuacji społecznej i interakcji dominują aspekty behawioralne: bodźcowo-reaktywne. 
Na podstawie tych definicji można utożsamić wymienione pojęcia. Nie istnieją pewnie interakcje niespołeczne, choć trzeba zasygnalizować, że sytuacja społeczna jest nie do końca tym samym co interakcja społeczna.

Theodore M. Newcomb, Ralph H. Turner i Philip E. Converse (1970) przez interakcję rozumieją coś więcej niż psychiczną i behawioralną aktywność dwóch lub więcej osób. Uważają oni, że interakcja to równoczesna aktywność dwóch lub większej liczby osób, których działania są współzależne i/lub wzajemnie uwarunkowane. Osoby będące w interakcji ustosunkowują się do siebie, a ustosunkowanie to może mieć charakter jednoczesny (jak w tańcu) lub naprzemienny (jak w rozmowie). Istotą interakcji jest wywieranie wpływu. Dzieje się to za pośrednictwem komunikacji i „polega na przekazywaniu jednej osobie przez drugą albo energii, albo informacji” (Newcomb, Turner i Converse, 1970: 206).

Według Elżbiety Dryll (2001: 8) przez: „interakcję społeczną rozumiemy zarówno akt komunikacyjny, jak i aktywność nakierowaną na przedmiot pozostający we wspólnym polu uwagi, zarówno o charakterze współpracy, jak i walki (rywalizacji) w dowolnie zarysowanym planie czasowym”. W definicji tej warto wskazać na dwojakie rozumienie interakcji: jako aktu komunikacyjnego i aktywności, która nie musi mieć koniecznie charakteru komunikacyjnego.

Michael Argyle (1999) również używa pojęć interakcji społecznej oraz sytuacji społecznej. Jego zdaniem interakcje społeczne zachodzą m.in. podczas wspólnej pracy czy spędzania wolnego czasu z przyjaciółmi. Aby mogły zaistnieć, konieczna jest koordynacja i zsynchronizowanie zachowań społecznych N i O. Gdy interlokutorzy jednocześnie mówią przez cały czas, wykrzykują polecenia lub zadają pytania - to zdaniem Argyle’a interakcja społeczna w ogóle się nie pojawia.

Podsumowując, warto wskazać na następujące cechy interakcji społecznych/interakcji:

- osoba i jej zachowanie mogą być/są bodźcem dla drugiej osoby i odwrotnie,

- wzajemność ustosunkowania się,

- równoczesność aktywności, jej współzależność i wzajemne uwarunkowanie,

- koordynacja i synchronizacja zachowań społecznych N i O,

- wywieranie wpływu.

Na podstawie przyjętego wcześniej założenia, że proces komunikacji przebiega od interakcji do komunikacji i dalej niekiedy do kontaktu, można się zastanawiać, czy jeśli N i O są w interakcji, to również niejako automatycznie 
się komunikują. Ustosunkowanie się do tej kwestii wymaga odpowiedzi na pytanie, czy istnieją interakcje bez komunikacji, oraz dwa wcześniej zadane pytania o naturę komunikacji i mechanizm przechodzenia od interakcji do komunikacji. Problem jest jeszcze bardziej interesujący, gdy zdamy sobie sprawę z tego, że oglądając dwie osoby będące w interakcji, odnosimy graniczące niemalże z pewnością wrażenie, że one również w tym samym czasie się komunikują. Czy jednak nie może być tak, że za tym, co wydaje się naturalne i oczywiste, kryją się pewne prawidłowości na pierwszy rzut oka niedostrzegalne?

Przykładem interakcji bez komunikacji wydaje się zachowanie kierowców na drodze o dwóch pasach ruchu. Kierowcy korzystający z takiej drogi, jadący w przeciwnych kierunkach, spostrzegają siebie nawzajem, niewątpliwie traktują siebie jako bodźce i zwracają uwagę na swoje zachowania. Każdy z nich pilnuje swojego pasa ruchu i wykazuje szczególną ostrożność podczas wyprzedzania. Kierowcy „trwają” zatem w interakcji. Gdy jednak kierowca sygnalizuje manewr wyprzedzania albo miga krótko długimi światłami, to jego zachowanie nabiera innego charakteru niż dotychczasowe. Komunikaty te są nadawane dla kogoś w pewnym celu. W tym momencie widać również, jak aspekt indywidualny komunikacji (konkretne zachowanie kierowcy) łączy się z jej aspektem społecznym (komunikat jest przeznaczony dla kogoś i jest kulturowo determinowany).

Innym przykładem interakcji bez komunikacji jest sytuacja opisana przez Paula Watzlawicka w wywiadzie udzielonym Carol Wilder (za: Mattelart i Mattelart, 2001). Watzlawick, biorący udział w sympozjum naukowym, podczas przerwy wrócił do swojego bungalowu, aby wyciągnąć się na łóżku i nieco odpocząć. Bungalow ten składał się z dwóch odrębnych pokojów, przedzielonych cienką ścianką działową. Po pewnej chwili do drugiej części domku powrócił jego przyjaciel, który zaczął robić coś, co przypominało stepowanie. Watzlawick postanowił leżeć cicho na łóżku i nie dawał znaku życia, aby nie wprawić przyjaciela w zakłopotanie swoją obecnością.

W ,sytuacji stepowania” nie ma intencjonalnego przekazywania komunikatu: ,ja stepuję i robię to specjalnie w taki sposób, abyś odebrał ten komunikat jako przeznaczony dla ciebie i nadał mu takie samo znaczenie, jakie i ja mu nadaję". Jest tu raczej intencjonalne nieprzekazywanie komunikatu o swojej obecności w drugiej części domku. Co najwyżej w omawianej tutaj sytuacji doszło do zakomunikowania pewnego zachowania - stepowania, ale nie doszło do komunikowania się między $\mathrm{N}$ i O.

Antonina Kłoskowska (1983) uważa, że znaczna część kultury społecznej polega na komunikowaniu się, czyli na interakcjach semiotycznych, jednak 
nie wszystkie interakcje społeczne mają charakter semiotyczny. Pisze ona, że chodzi o: „takie przebiegające wg ustalonych wzorów interakcje pomiędzy ludźmi, które nie mają charakteru semiotycznego, a są szczególnie ważne dla ludzi. Są to zabiegi fizycznej pielęgnacji i opieki, leczniczej pomocy, czynności seksualne, walka prowadząca do różnych form fizycznego unieszkodliwiania przeciwnika. Wszystkie te działania polegają na fizycznym operowaniu ciałem innego człowieka” (Kłoskowska, 1983: 255). Autorka uważa, że w podanych sytuacjach: „tkwi [...] podstawowy akt interakcji zewnętrznej w stosunku do znaczeń [...], a posiadający ważność społeczną i indywidualną. Ten akt będzie określany jako residuum interakcyjne” (s. 255-256) ${ }^{1}$.

Reasumując, przejście od interakcji do komunikacji nie odbywa się automatycznie. Wymaga ono określonych czynności i działań ze strony N względem O. Omówimy je po wcześniejszym przedstawieniu zagadnienia komunikacji.

Komunikacja jest najczęściej łączona z przekazywaniem wiadomości zawierającej informację/informacje, a także z przekazywaniem znaczeń. Lawrence R. Fray, Carl H. Botan i Gary L. Kreps (2000) uważają, że komunikacja jest procesem takiego organizowania wiadomości, aby stworzyć i przekazać znaczenie. Zdaniem Georges’a A. Millera (1980: 157) „komunikacja zachodzi wówczas, gdy zdarzenia w jednym miejscu i czasie są ściśle związane ze zdarzeniami w innym miejscu i czasie”. Arthur S. Reber i Emily S. Reber (2008: 327) w Słowniku psychologii podają, że komunikacja jest transferem czegoś z jednego miejsca do innego: „Tym «czymś» może być wiadomość, sygnał, znaczenie itp. Warunkiem koniecznym zajścia komunikacji jest posiadanie wspólnego kodu przez nadawcę i odbiorcę, by znaczenie czy informacje zawarte w przekazie mogły być bezbłędnie zinterpretowane”.

Abraham A. Moles (1986) uważa, że komunikowanie się jest czynnością pozwalającą na uczestniczenie w bodźcach i doświadczeniach innej osoby oraz wymianę tych doświadczeń z zastosowaniem elementów wiedzy, które są dla nich wspólne. Margaret Bullowa (1980) jest zdania, że komunikacja zachodzi w trakcie interakcji. Przejście od interakcji do komunikacji staje się możliwe, gdy spełnione zostaną dwa warunki: 1. treść wymieniana między interlokutorami ma dla nich przynajmniej podobne, jeśli nie identyczne znaczenie; 2. komunikat jest nadawany w taki sposób, aby został odebrany przez $\mathrm{O}$ zgodnie z intencją $\mathrm{N}$.

1 Swoją drogą, ciekawe, czy wizyta u kiepskiego, ciągle milczącego lekarza lub fizjoterapeuty mogłaby być uznana za interakcję rezydualną (inaczej: szczątkową, resztkową)? 
Według Normana Gista (zob. Hartley i Hartley, 1961: 26): „Gdy interakcja społeczna zakłada przenoszenie znaczeń za pomocą symboli, nazywa się ją komunikowaniem”. Ursula K. Le Guin z kolei podkreśla intersubiektywny charakter komunikowania się twarzą w twarz. Pisze ona: „Intersubiektywność jest wzajemna. Jest to ciągła wymiana między dwiema świadomościami” (Le Guin, 2004: 188).

Ponawiając postawione wcześniej pytanie o to, kiedy jest możliwe przejście od interakcji do komunikacji, jakie są warunki i ewentualny mechanizm tego przejścia, należy stwierdzić:

- Zachowania nie mają charakteru intencjonalnego, czynności natomiast tak. Czynności komunikacyjne są celowe i intencjonalne, natomiast w interakcji zachowania $\mathrm{N}$ mogą, ale nie muszą być bodźcem dla $\mathrm{O}$.

- Przekazanie i odebranie komunikatu przez $\mathrm{N}$ i O wymaga posługiwania się przez nich wspólnym kodem o charakterze symbolicznym.

- Przekazywane komunikaty mają przynajmniej podobne znaczenie dla $\mathrm{N}$ i O.

- Komunikat przygotowany i wysłany przez N powinien uwzględniać możliwości jego odbioru i zrozumienia przez O. N powinien brać również pod uwagę kontekst społeczny, w którym zachodzi komunikacja. W tym rozumieniu komunikat jest zawsze dla kogoś i występuje w określonej sytuacji. W ten sposób realizuje się aspekt społeczny komunikacji.

- W interakcji jej uczestnicy percepcyjnie się wyodrębniają, w komunikacji dodatkowo poznawczo opracowują przekazane informacje.

Interakcja nie jest zatem tożsama z komunikacją. Przejście od interakcji do komunikacji nie następuje samo z siebie, automatycznie. Wymaga ono określonego wysiłku, czynności i działań N i O. Mechanizm tego przejścia wart dalszego zgłębiania - zawiera, naszym zdaniem, przynajmniej niektóre z wyżej wymienionych prawidłowości, w procesie komunikacji podlegające regulacji i koordynacji.

W procesie komunikacji interpersonalnej $\mathrm{N}$ i O, komunikując się, czasami nawiązują między sobą kontakt. Według Johna Stewarta (2000) dwie osoby są w kontakcie, gdy ich sposób komunikowania się maksymalizuje to, co osobiste. Dla Barbary Bokus (1984) wyznacznikiem kontaktu jest wspólne pole uwagi. Może ono obejmować wspólny przedmiot percepcji lub działania czy wspólny temat rozmowy. Teresa Szustrowa (1987) z kolei uważa, że kontakt nie jest stałą cechą relacji interpersonalnych. Jest on możliwy wtedy, gdy $\mathrm{N}$ i O zachowują wobec siebie pełną otwartość, a ich koncentracja uwagi na sobie i na partnerze komunikacji nie ma charakteru obronnego. Kontakt jest zatem szczególnego rodzaju relacją interpersonalną, charakteryzującą 
się bliskością psychiczną i niekiedy fizyczną oraz wzajemnym zaufaniem. Uwaga interlokutorów jest przy tym skierowana na jakiś wspólny przedmiot, temat rozmowy czy problem - występuje więc wspólna aktywność.

Podsumowując, pojęcia interakcji, komunikacji i kontaktu nie są tożsame, ponieważ odnoszą się do odmiennych, aczkolwiek powiązanych ze sobą zjawisk. Spośród cech zasadniczo je różniących należałoby wymienić intencjonalność i symboliczne przekazywanie znaczeń dla pary: interakcja-komunikacja oraz bliskość i zaufanie dla pary: komunikacja-kontakt. Proces komunikacji przebiega zatem od interakcji do komunikacji i dalej do kontaktu. Zależności te można rozpatrywać przyczynowo-skutkowo albo cyrkularnie. W pierwszym ujęciu mamy do czynienia z procesem komunikacji zachodzącym „tu i teraz”, czyli z jednokrotnym aktem przechodzenia od interakcji do komunikacji i ewentualnie nawiązania kontaktu. Inaczej: interakcja warunkuje komunikację, a one z kolei warunkują nawiązanie kontaktu. Natomiast w ujęciu cyrkularnym ostatni element procesu komunikacji warunkuje pojawienie się pierwszego. Zatem z osiągnięcia kontaktu może wynikać dalsza interakcja i komunikacja. Jak zauważają Robert Hinde i Joan Stevenson-Hinde (1987), powtarzające się w czasie interakcje mogą doprowadzić do wytworzenia się między N i O określonych stosunków. Ujęcie cyrkularne dotyczy zatem powtarzalnych interakcji i dłuższej perspektywy czasu.

Na podstawie przedstawionych powyżej poglądów warto zauważyć, że nie każda interakcja jest komunikacją oraz nie każda komunikacja umożliwia nawiązanie kontaktu. Natomiast wydaje się, że każdy kontakt i komunikacja są wpisane w interakcję.

\section{Wymiary komunikacji interpersonalnej}

W przebiegu procesu komunikacji interpersonalnej zachodzą różne zmiany, które nazywamy jego formami zmienności. Są one podstawowymi elementami, z których ten proces jest zbudowany. Do form zmienności procesu komunikacji interpersonalnej należą m.in. wymiary komunikacji. „Są one traktowane jako naturalne wymiary komunikacji interpersonalnej - naturalne, czyli przyrodniczo ujęte w sensie kategorii naturalnych"2.

${ }^{2}$ Cytat jest wypowiedzią prof. Krystyny Zamiary w czasie dyskusji podczas seminarium naukowego Zakładu Historii i Metodologii Nauk o Kulturze w roku akademickim 2009/2010 w Instytucie Kulturoznawstwa UAM - po wygłoszeniu referatu pt. Wymiary komunikacji interpersonalnej autorstwa S. Frydrychowicza. 
Określenie „wymiary komunikacji” wskazuje zatem na ważne płaszczyzny, które zawierają się w komunikacji, a ich regulacja i koordynacja jest podstawą przebiegu procesu komunikacji interpersonalnej. Innymi formami zmienności są również parametry werbalne komunikacji (np. wypowiedź składająca się z wyrazów i zdań oraz zawartego w nich sądu), paralingwistyczne (np. natężenie głosu, intonacja, tempo mówienia) oraz niewerbalne, jak gesty, mimika czy dystans.

Poniżej scharakteryzujemy cztery wymiary komunikacji: informacyjny, emocjonalno-energetyczny, współdziałania (wspólnego wykonywania czegoś) oraz relacyjny. Warto też wspomnieć, że Friedemann Schulz von Thun (2005) zaproponował cztery wymiary wypowiedzi: zawartość rzeczową, relację wzajemną, ujawnianie siebie oraz apel (służący wywieraniu wpływu, osiąganiu celu).

Prezentację wymiarów rozpoczniemy od wymiaru informacyjnego. Można tutaj oprzeć się na następującej definicji: „Informacja [...] jest miarą przewidywalności sygnałów, którą stanowi ilość możliwych wyborów dokonywanych przez nadawcę” (Fiske, 1999: 24). Parafrazując, im więcej możliwych wyborów niesie przekaz, tym więcej jest w nim zawartych informacji. Porzućmy jednak definicje informacji o cybernetycznej proweniencji. Ponieważ komunikacja ma charakter indywidualno-społeczny, ważne jest nie tylko to, że informacja zmniejsza czyjąś niepewność (np. gdy pytam kogoś o nieznaną mi ulicę w obcym mieście), ale również to, że jest przeznaczona dla kogoś - co oznacza, że powinna być do tej osoby dostosowana. Zatem N staje przed trudnym zadaniem rozpoznania aktualnego stanu wiedzy O i dokonania wyboru informacji i takiego sposobu ich przekazania, aby interlokutor nie tylko mógł informacje te odebrać, ale również dokonać ich odpowiedniej interpretacji.

Aby komunikacja była efektywna, przekaz powinien zawierać istotne informacje. Istotna informacja to informacja ważna, coś wnosząca, zmieniająca wiedzę, doświadczenie odbiorcy. Ważne jest też przestrzeganie podstawowych reguł konwersacji (Grice, 1980), np. reguły ilości dotyczącej tego, że powinniśmy przekazać odbiorcy tyle informacji, ile trzeba - ani nie za mało, ani nie za dużo. Ilość przekazywanej informacji może zależeć zarówno od potrzeb i celów N, od potrzeb $\mathrm{O}$, jak i od sytuacji, w której odbywa się proces komunikacji. Jeśliby rozpatrywać akty mowy jako podstawowe jednostki komunikacji, to zastosowanie w wymiarze informacyjnym znajduje również tzw. warunek przygotowawczy lub wstępny, dotyczący różnicy w poziomie informacji między N i O (Searle, 1987; Kurcz, 2000).

Podsumowując, dzięki przekazywaniu istotnych, ważnych informacji można wzbogacić wiedzę odbiorcy, a także poprzez informację wywierać 
na niego wpływ, kształtując jego potrzeby, poglądy i wybory. Dodajmy, że ważne jest to, aby te zmiany miały pozytywny charakter zarówno w wymiarze indywidualnym, jak i społecznym. Aby jednak tak się stało, przekaz informacji powinien zawierać odpowiednią dozę emocji i energii.

Kolejny wymiar komunikacji stanowi wymiar emocjonalno-energetyczny. Jego istotą jest stosunek emocjonalny $\mathrm{N}$ do komunikatu oraz do $\mathrm{O}$ tego komunikatu. W wymiarze tym mieszczą się też tradycyjne już funkcje języka: ekspresywna i impresywna (Jakobson, 1989). Natomiast energetyczność przekazu może być łączona z kilkoma kwestiami. Świadczy ona, po pierwsze, o zaangażowaniu $\mathrm{N}$ i O w sam proces komunikacji w czasie jego trwania. Wprawdzie Sherwyn P. Morreale, Brian H. Spitzberg i J. Kevin Barge (2007) piszą o motywacji do komunikowania się, ale dotyczy ona nie tyle podtrzymywania procesu komunikacji, ile doprowadzenia do takiego stanu, że N i O chcą się komunikować. Po drugie, energetyczność przekazu dowodzi autentyczności zaangażowania w sprawę, która jest przedmiotem komunikacji. Dobrym wskaźnikiem tego zaangażowania jest natężenie głosu, które wzrasta w momentach przekonania N o słuszności jego wywodu i trafności realizacji intencji wypowiedzi (Frydrychowicz, 1999; Bręński, 2015). Po trzecie, energetyczność przekazu wpływa na motywację $\mathrm{N}$ i O do zmiany/rekonstrukcji ich doświadczenia i podjęcia w związku z tym działań ukierunkowanych na związany z tą rekonstrukcją cel. W tym rozumieniu energetyczność przekazu stanowi czynnik wywierania wpływu. Jest to zgodne ze stwierdzeniem Newcomba, Turnera i Converse’a (1970), że w interakcji wpływ jest wywierany za pośrednictwem komunikacji, a w jej ramach za pomocą informacji i energii.

Aby wymiar emocjonalno-energetyczny pełnił w procesie komunikacji interpersonalnej wskazane powyżej funkcje, niezbędne jest zrównoważenie emocji i energii. Zrównoważenie to oznacza dostosowanie poziomu emocji i energii do wagi tematu, stanu psychicznego $\mathrm{N}$ i O oraz celu, który ma zostać osiągnięty. Prowadzenie trudnej rozmowy z interlokutorem wymaga zarówno odpowiedniego poziomu energii (zaangażowanie), jak i optymalnego poziomu emocji. Pozwala to zachować kontrolę poznawczą nad tym, co i jak się mówi, i nie indukować u odbiorcy nadmiernych, a zwłaszcza negatywnych emocji.

Wymiar wspólnego wykonywania czegoś, współdziałania to trzecia płaszczyzna procesu komunikacji. Proces komunikacji współtworzą N i O, a to oznacza, że sytuacja komunikacji, w której oni uczestniczą, jest inna dla każdego z nich i wymaga uzgodnienia. Jest ono możliwe w ramach wspólnej płaszczyzny porozumienia (dalej - WPP). Płaszczyzna ta zawiera uwspólnione znaczenia, wiedzę, doświadczenia, cele i działania, jest zatem swoistego rodzaju pomostem, wspólnym mianownikiem dla $\mathrm{N}$ i O. W ramach WPP jest 
możliwe wspólne myślenie na jakiś temat, wspólne rozwiązywanie problemu i podjęcie wspólnego działania, aby ten problem rozwiązać. Warto przy tym zauważyć, że w ramach WPP zintegrowaniu podlegają doświadczenie i działanie dwóch lub większej liczby osób. Następuje zatem łączenie tego, co indywidualne, z tym, co społeczne (perspektywa innych osób).

Ważna jest tutaj idea wkładu. Chodzi o uświadomienie sobie przez $\mathrm{N}$ i O, że rozwiązywanie problemów, zaproponowanie nowych rozwiązań itp. wymaga przynajmniej w miarę symetrycznego udziału obu stron w tych czynnościach. Współdziałanie jest możliwe na bazie wspólnie podzielanej wiedzy (wspólny grunt) na temat wspólnych działań, co z kolei umożliwia podejmowanie przez uczestników procesu komunikacji wspólnych czynności (Clark, 1996). Wreszcie prawidłowa realizacja omawianego wymiaru umożliwia przejście od komunikowania się do nawiązania kontaktu.

Warto przypomnieć, że wymiar wspólnego wykonywania czegoś, współdziałania ma swoje genetyczne (w sensie początku) umocowanie w rozwoju zachowań intencjonalnych dziecka. Michael Tomasello (2002: 86) uważa, że między 9. a 12. miesiącem życia pojawia się nowy typ zachowań dziecka: „Zachowania niemowląt przestają mieć - jak to było do tej pory - charakter dwustronny, a stają się trójstronne, w tym sensie, że obejmują skoordynowane interakcje z innymi ludźmi i z przedmiotami, w wyniku czego powstaje trójkąt odniesieniowy: dziecko-dorosły-przedmiot lub zdarzenie, będący obiektem obopólnej uwagi. Termin «wspólna uwaga» najczęściej jest używany właśnie na określenie takiego złożonego układu społecznych interakcji”.

Reasumując, wzajemne „odczytywanie” intencji komunikacyjnych, zapoczątkowane między 9. a 12. miesiącem życia, jak również wspólne ukierunkowanie uwagi w ramach tzw. wspólnej sceny (sytuacji współdziałania i podzielania uwagi) oraz dzięki temu wzajemne przekazywanie perspektyw spostrzegania i rozumienia rzeczywistości jest możliwe w ramach interakcji społecznych konkretyzujących się w procesie komunikacji interpersonalnej i sytuacji komunikacji.

Czwarty wymiar komunikacji - relacyjny - dotyczy relacji między interlokutorami. Paul Watzlawick, Janet Helmick Beavin i Don D. Jackson (1972) uważają, że komunikacja zakłada zaangażowanie się N i O, a to prowadzi do powstania określonej relacji między nimi.

Istnieją dwa podstawowe typy relacji między interlokutorami: symetryczny i komplementarny. Dla relacji symetrycznej między N i O charakterystyczna jest równość i wzajemne odzwierciedlanie zachowań, dla relacji komplementarnej z kolei - uzupełnianie zachowania jednego partnera przez zachowania drugiego. W relacji komplementarnej jedna osoba 
zajmuje pozycję wyższą, a druga niższą, podrzędną. Obydwa typy relacji determinowane są kontekstem społecznym i kulturowym, np. kompetencjami komunikacyjnymi i społecznymi rozmówców, usankcjonowanymi sposobami zwracania się do siebie, związanymi z pełnionymi rolami, czasem trwania mówienia/słuchania i zwyczajowo przysługującym prawem kończenia rozmowy. I tak komunikacja między przyjaciółmi może mieć charakter symetryczny, natomiast relacja lekarz-pacjent czy ksiądz-wierny ma zwykle charakter komplementarny.

Mimo że relacja komplementarna powstaje w społecznym kontekście (np. nauczyciel-uczeń), to może ona też wynikać ze szczególnego układu między osobami. Nie zawsze jest tak, że N i O narzucają sobie zachowanie komplementarne. Czasami ich specyficzny sposób zachowania (np. nadmierna uległość) wyzwala określony typ relacji. Ważne jest jednak, aby tam, gdzie to możliwe i potrzebne, relację komplementarną zamieniać na relację chociaż nieco bardziej symetryczną, zwłaszcza gdy komunikacja dotyczy spraw trudnych. Zwiększenie równości partnerów może w znacznym stopniu przyczynić się do lepszego przekazywania niełatwych informacji i głębszego przemyślenia treści, które niosą.

Zaznaczyliśmy wcześniej, że proces komunikacji interpersonalnej jest współtworzony przez interlokutorów oraz odbywa się w określonej sytuacji, którą możemy nazwać sytuacją komunikacji. Sytuacja ta jest nasycona w różnym stopniu wymiarami komunikacji (regulacja), jak również mamy do czynienia ze specyficzną dla niej koordynacją wymiarów. Regulacja i koordynacja wymiarów komunikacji wchodzą w skład mechanizmu scalania form zmienności procesu komunikacji. Aby zilustrować, jak wygląda regulacja i koordynacja wymiarów komunikacji, posłużmy się tutaj przykładem typowej spokojnie przebiegającej rozmowy między szefem a pracownikiem na temat np. aktualnego stanu firmy i konkurencyjności jej produktów. Sytuację tę przedstawia rysunek 1 .

Nasycenie tej sytuacji komunikacji każdym z wymiarów jest na poziomie średnim, z lekkim podwyższeniem wymiaru informacyjnego oraz wymiaru relacyjnego w kierunku komplementarności. Załóżmy jednak, że dalej rozmowa nie przebiega już tak spokojnie, co jest spowodowane tym, że szef zaczyna mówić o konieczności wprowadzenia nowej gamy produktów i czyni za to odpowiedzialnym pracownika - wbrew jego woli. W tej sytuacji należy się spodziewać znacznego wzrostu wymiaru emocjonalno-energetycznego, redukcji wymiaru współdziałania oraz dalszego wzrostu wymiaru relacyjnego w kierunku zwiększenia komplementarności. Sytuację tę przedstawia rysunek 2. 


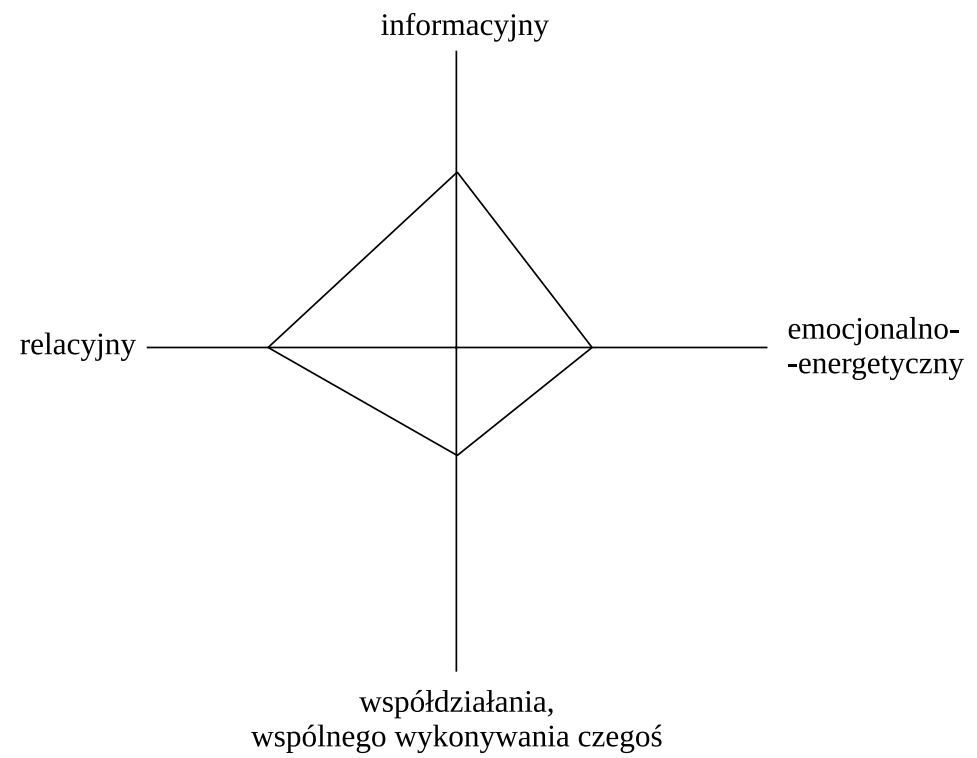

Rysunek 1. Wymiary komunikacji interpersonalnej w trakcie spokojnej rozmowy między szefem i pracownikiem Źródło: opracowanie własne.

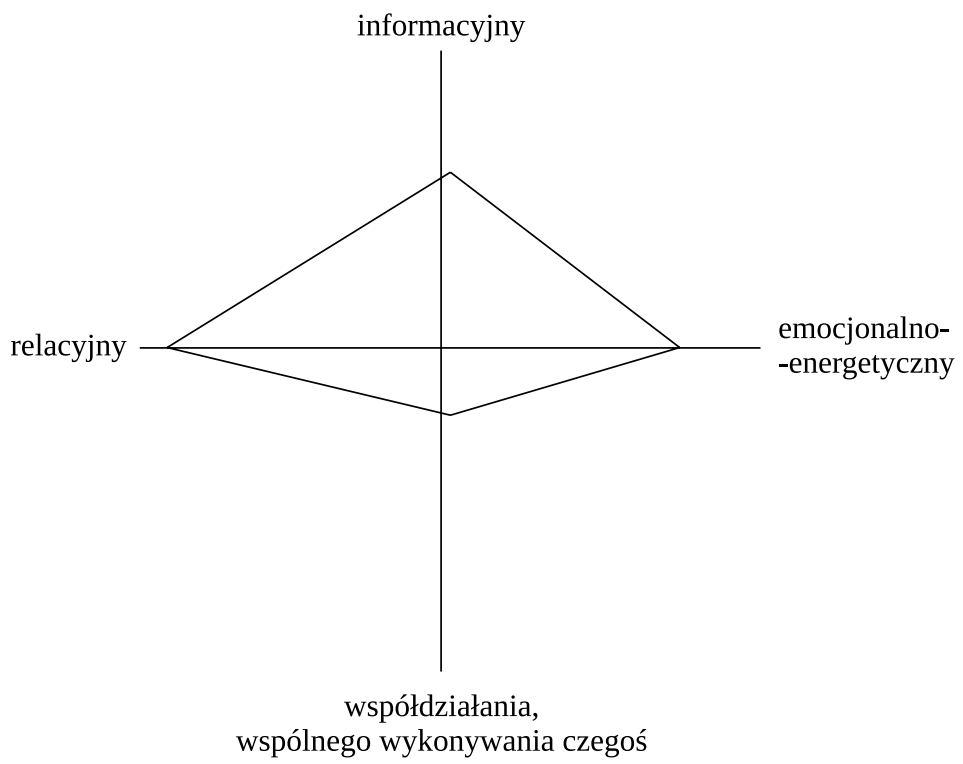

Rysunek 2. Wymiary komunikacji interpersonalnej

$\mathrm{w}$ trakcie niespokojnej rozmowy między szefem i pracownikiem Źródło: opracowanie własne. 
Czytelnikowi pozostawiamy rozstrzygnięcie kwestii regulacji i koordynacji wymiarów, gdyby między szefem a pracownikiem doszło do kłótni, oraz zadanie takiego wyregulowania wymiarów komunikacji, aby była szansa powrotu do przynajmniej w miarę spokojnej rozmowy.

\section{Efektywna komunikacja interpersonalna w świetle struktury procesu komunikacji}

Niewątpliwie prawdziwe jest stwierdzenie Virginii Satir (2000), że powinniśmy porzucić marzenie o całkowicie jednoznacznej komunikacji, gdyż z samej swej natury jest ona niekompletna. Nie podważa to jednak słuszności wysiłków służących zwiększeniu jej efektywności. Efektywność komunikacji jest kojarzona z komunikowaniem się sprawnym i skutecznym. Sprawne komunikowanie się oznacza, że wiemy, jak się komunikować, mamy odpowiednią wiedzę, kompetencje komunikacyjne i społeczne w tym zakresie. Skuteczne komunikowanie się oznacza, że wiemy, jak osiągnąć cel, najlepiej stosując jak najbardziej oszczędne strategie. Z powyżej przeprowadzonej analizy ustrukturowania procesu komunikacji interpersonalnej wynikają ważne kwestie dla efektywnego komunikowania się interlokutorów. Poniżej omówimy niektóre z nich.

Interakcja to pewien „akt możności”, który może, lecz nie musi zostać przekształcony przez $\mathrm{N}$ i O w komunikację i kontakt. Ważne jest uświadomienie sobie, że proces komunikacji przebiega od interakcji do komunikacji i do kontaktu, ale nie dzieje się to samoistnie. Przejście to wymaga określonego wysiłku od interlokutorów. Ważne jest również uświadomienie sobie, na którym z etapów tego procesu jesteśmy (interakcja? komunikacja? kontakt?) w aktualnym przebiegu procesu komunikacji i w jaki sposób przejść do następnego.

Na szczęście nie wszystkie sytuacje komunikacji obligują nas do nawiązania kontaktu. Prowadzenie zwykłej rozmowy z urzędnikiem czy pracownikiem banku na jakiś niezbyt trudny temat sprowadza się zapewne do interakcji i komunikacji. Nawiązanie kontaktu w tej sytuacji nie jest imperatywem. W rozmowie z bliską osobą - przeciwnie, warto będzie uzupełnić interakcję i komunikację o kontakt.

Dla efektywnej komunikacji ważna jest też intencjonalność. Sformułowanie wypowiedzi przez $\mathrm{N}$ zgodnie z jego intencją oraz odebranie wypowiedzi przez $\mathrm{O}$ zgodnie z intencją $\mathrm{N}$ zwiększają prawdopodobieństwo porozumienia między nimi, czyli inaczej skomunikowania się i nawiązania 
kontaktu. Warto też pamiętać o tym, że komunikacja jest współtworzona, co zakłada konieczność wzajemnego dostosowania się interlokutorów nie tylko w obszarze komunikacji, ale również poznawczym i emocjonalnym. Dlatego dla efektywnej komunikacji nie jest, być może, tak bardzo ważne to, co $\mathrm{N}$ myśli o problemie trapiącym $\mathrm{O}$ i o tym, jak ten chce go rozwiązać oraz co w związku z nim czuje. Ważne natomiast jest to, czy i jak N pojmuje czyjeś rozumienie problemu i czy podziela/odzwierciedla odczucia i emocje z tym związane oraz w sposób umiejętny i wyważony daje temu wyraz w trakcie komunikowania się.

Istotna też jest odpowiednia do potrzeb i celów interlokutorów oraz do sytuacji komunikacji regulacja i koordynacja wymiarów komunikacji. Umożliwia ona nie tylko podtrzymanie komunikowania się, ale również nawiązywanie kontaktu. Ponadto efektywne komunikowanie, w którym są odpowiednio wyregulowane i skoordynowane wymiary komunikacji, przyczynia się do integrowania relacji międzyludzkich nie tylko wewnątrz rodziny czy w szkole, ale w wielu innych organizacjach społecznych (Frydrychowicz, 2020).

\section{Podsumowanie}

Komunikacji interpersonalnej nie można sprowadzić jedynie do przekazywania informacji. Przebiega ona jeszcze w trzech pozostałych wymiarach. W każdej sytuacji komunikacji jej wymiary mogą wystąpić w innych proporcjach oraz wymagać innej regulacji i koordynacji ze strony interlokutorów. Wiedza i umiejętności dotyczące powyżej omawianych prawidłowości procesu komunikacji są elementami kompetencji komunikacyjnej i społecznej. Ich wykorzystanie może być istotne dla efektywnego komunikowania się nie tylko w sytuacjach formalnych, w których komunikacja pełni funkcję instrumentalną, ale również w sytuacjach nieformalnych, w których komunikowanie się może się wiązać chociaż z odrobiną przyjemności związaną z wchodzeniem w relacje z innymi ludźmi. 


\section{Literatura}

Argyle, M. (1999). Psychologia stosunków międzyludzkich. Warszawa: Wydawnictwo Naukowe PWN.

Bertalanffy, L. von (1984). Ogólna teoria systemów. Warszawa: Państwowe Wydawnictwo Naukowe.

Bokus, B. (1984). Nawiq̨zywanie interakcji społecznych przez małe dziecko. WrocławWarszawa-Lublin-Poznań-Kraków: Ossolineum.

Bręński, S. (2015). Wpływ prawdopodobieństwa fonotaktycznego na przetwarzanie języka. Psychologia Rozwojowa, 20, 23-37.

Bullowa, M. (1980). The beginnings of interpersonal communication. Cambridge: Cambridge University Press.

Clark, H.H. (1996). Using language. Cambridge, MA: Cambridge University Press.

Crystal, D. (1990). The Cambridge encyclopedia of language. Cambridge-New York-Port Chester-Melbourne-Sydney: Cambridge University Press.

Dryll, E. (2001). Interakcja wychowawcza. Warszawa: Wydawnictwo Instytutu Psychologii PAN.

Fiske, J. (1999). Wprowadzenie do badań nad komunikowaniem się. Wrocław: Astrum.

Fray, L.R., Botan, C.H., Kreps, G.L. (2000). Investigating communication: An introduction to research methods. Boston: Allyn \& Bacon.

Frydrychowicz, S. (1999). Proces mówienia. Wybrane psychologiczne aspekty na przykładzie interpretacji zdania niejednoznacznego. Poznań: Wydawnictwo Naukowe UAM.

Frydrychowicz, S. (2020). Interakcje społeczne. W: J. Trempała, H. Liberska (red.), Psychologia wychowania. Wybrane problemy (s. 280-291). Warszawa: Wydawnictwo Naukowe PWN.

Grice, H.P. (1980). Logika a konwersacja. W: B. Stanosz (red.), Język w świetle nauki (s. 91-114). Warszawa: Czytelnik.

Hartley, E.G., Hartley, R.E. (1961). Fundamentals of Social Psychology. New York: Alfred A. Knopf.

Hinde, R., Stevenson-Hinde, J. (1987). Interpersonal relationship and child development. Developmental Reviev, 7, 1-21.

Jakobson, R. (1989). Poetyka w świetle językoznawstwa. W: M.R. Mayenowa (red.), W poszukiwaniu istoty języka (s. 77-124). Warszawa: Państwowy Instytut Wydawniczy.

Kłoskowska, A. (1983). Socjologia kultury. Warszawa: Państwowe Wydawnictwo Naukowe.

Kurcz, I. (2000). Psychologia języka i komunikacji. Warszawa: Wydawnictwo Naukowe Scholar.

Le Guin, U.K. (2004). The wave in the mind. Talks and esseys on the writer, the reader, and the imagination. Boulder: Shambhala Publication.

Mattelart, A., Mattelart M. (2001). Teorie komunikacji. Krótkie wprowadzenie. WarszawaKraków: Wydawnictwo Naukowe PWN.

Miller, G.A. (1980). Psychologia i komunikacja. W: B. Stanosz (red.), Język w świetle nauki (s. 157-167). Warszawa: Czytelnik.

Moles, A.A. (1986). Théorie structural de la communications et société. Paris: Masson. 
Morreale, S.P., Spitzberg, B.H., Barge, J.K. (2007). Komunikacja między ludźmi. Warszawa: Wydawnictwo Naukowe PWN.

Newcomb, Th.M., Turner, R.H., Converse, Ph.E. (1970). Psychologia społeczna. Warszawa: Państwowe Wydawnictwo Naukowe.

Reber, A.S., Reber, E.S. (2008). Stownik psychologii. Warszawa: Wydawnictwo Naukowe Scholar.

Satir, V. (2000). Terapia rodziny. Gdańsk: Gdańskie Wydawnictwo Psychologiczne.

Searle, J.R. (1987). Czynności mowy. Warszawa: Instytut Wydawniczy Pax.

Schulz von Thun, F. (2005). Sztuka rozmawiania. Analiza zaburzeń. Kraków: Wydawnictwo WAM.

Stewart, J. (2000). Komunikacja interpersonalna: kontakt między osobami. W: J. Stewart (red.), Mosty zamiast murów (s. 36-66). Warszawa: Wydawnictwo Naukowe PWN.

Szewczuk, W. (red.). (1979). Słownik psychologiczny. Warszawa: Wiedza Powszechna.

Sztompka, P. (2016). Kapitał społeczny. Teoria przestrzeni międzyludzkiej. Kraków: Wydawnictwo Znak.

Szustrowa, T. (1987). Swobodne techniki diagnostyczne. Warszawa: Wydawnictwo Uniwersytetu Warszawskiego.

Tomasello, M. (2002). Kulturowe uwarunkowania ludzkiego poznawania. Warszawa: PIW. Tyszkowa, M. (1990). Rodzina, doświadczenie i rozwój jednostki. Paradygmat teoretyczny badań. W: M. Tyszkowa (red.), Rodzina a rozwój jednostki (s. 13-37). Poznań: Nakładem Centralnego Programu Badań Podstawowych CPBP 09.02.

Watzlawick, P., Helmick-Beavin, J., Jackson, D.D. (1972). Une logique de la communication. Paris: Édition du Seuil. 